\title{
KERJA KURATORIAL DALAM EKSEBISI ARSIP DI INDONESIA
}

\author{
Lillyana Mulya, M.A., Trisna Pradita, S.Sos., M.M. \\ Prodi Kearsipan Sekolah Vokasi UGM, Tata Kelola Seni ISI Yogyakarta \\ (lillyana.mulya@ugm.ac.id, joseppradita@gmail.com)
}

\begin{abstract}
INTISARI
Mayoritas orang Indonesia saat ini melihat eksebisi sebagai praktik yang lekat dengan bidang seni dan budaya. Praktik ini kemudian diadopsi oleh bidang lain untuk konsep yang sama, yaitu sebagai media komunikasi antara produsen dan konsumen, baik dalam artian komersil maupun tidak komersil. Di era integrasi institusi memori, bidang arsip, sebagaimana juga dengan perpustakaan dan museum, menggunakan eksebisi sebagai strategi komunikasi untuk diseminasi informasi kepada masyarakat. Namun, eksebisi arsip di Indonesia masih terganjal pada pemahaman konsep kuratorial untuk menampilkan arsip dalam konteks. Kerja kuratorial menjadi fokus dalam kajian ini dengan terlebih dahulu mengajukan pertanyaan tentang gambaran eksebisi arsip di Indonesia dan persoalan kuratorial yang muncul dalam eksebisi arsip. Kajian ini memakai metode studi pustaka dan observasi lapangan untuk mendapatkan data mengenai praktik eksebisi arsip di Indonesia. Konten eksebisi kemudian dianalisis untuk kesesuaian objek dengan ide yang disampaikan. Kajian ini menyimpulkan bahwa melalui kerja kuratorial, eksebisi arsip mesti diperankan sebagai penyedia sumber-sumber reliabel sehingga mendapatkan tempat dalam produksi pengetahuan.
\end{abstract}

Kata kunci: arsip, eksebisi, kuratorial, Indonesia.

\section{ABSTRACT}

Most people in Indonesia see an exhibition as a practice that is closely related to the arts and culture. This practice was adopted by other fields for the same concept, which is a way of communication between producers and consumers, both commercial and non-commercial. In the era of integration of memory institutions, the field of archives, as well as libraries and museums, using exhibitions as a communication strategy to disseminate the information to the user or society. However, archival exhibitions in Indonesia are still hampered by curatorial understanding to display archives in context. Curatorial work is the focus of this study by first asking questions about how is the archival exhibition held in Indonesia and curatorial issues that arise in archival exhibitions. This study using literature study and field observation to obtain an image of archival exhibition practices in Indonesia. The content of the exhibition is then analyzed for the suitability of the objects with the exhibition ideas. This study concludes that through curatorial work, the archival exhibition must be played as a provider of reliable sources to gain a place in the production of knowledge.

Keywords: archives, curatorial, exhibition, Indonesia.

\section{PENGANTAR}

\section{Latar Belakang Masalah}

Kamus Besar Bahasa Indonesi memberikan definisi eksebisi atau pameran merupakan "pertunjukan hasil karya seni, hasil produksi dan sebagainya". Sementara dalam Oxford Dictionary, exhibition (pameran) diartikan lebih spesifik yaitu a public display of works of art or items of interest, held in an art gallery or museum or at a trade fair. Dalam definisi menurut kamus Oxford, interest (ketertarikan) menjadi batasan objek yang ditampilkan. Lebih lanjut, ketertarikan yang bersifat subjektif (bahkan arbitrer) mengarah pada konteks yang diletakkan 
oleh penyelenggara eksebisi yang berkaitan dengan ide atau pesan yang ingin disampaikan. Istilah kedua yang ada dalam definisi eksebisi versi Oxford adalah trade fair yang menunjukkan bahwa eksebisi juga digunakan untuk pertunjukan objek dalam arti komersil. Guna spesifikasi kajian, maka definisi Oxford dipilih sebagai rujukan dalam kajian ini. Pertimbangan ini terutama karena interest, yang mengarah pada konteks, merupakan fokus dalam kerja kuratorial yang dibahas lebih lanjut.

Secara lebih luas, eksebisi diasosiasikan dengan museum sebab pada awal perkembangannya, eksebisi merupakan kerja utama museum yang memamerkan koleksinya maupun koleksi pinjaman. Tujuan dari pertunjukan koleksi ini, secara historis adalah untuk menarik minat dan rasa ingin tahu masyarakat. Seni dan sejarah peradaban manusia, merupakan bidang yang pertama-tama dapat membangkitkan kekaguman publik atas sesuatu yang informatif dan indah di Eropa barat. Keingintahuan ini, menurut Mondello dalam wawancara yang direkam di https:// www.npr.org/templates/transcript/transcript.php ?storyId=97377145 kemudian berkembang menjadi ketertarikan atas sesuatu yang asing dan belum pernah mereka temui.

Referensi di Indonesia, tidak banyak sumber yang menceritakan tentang awal mula praktek eksebisi. Sebuah eksebisi yang tercatat dan dianggap sukses pertama kali adalah Pameran 1853 yang dirancang oleh para floracrat dalam Persatuan Naturalis Hindia Belanda (Natuurkundige Vereeniging in Nederlandsch Indië). Floracrat adalah sebutan untuk para penyelidik alam yang bekerja sebagai pegawai kolonial dalam proyek-proyek penelitian negara, dalam hal ini adalah penelitian aklimatisasi tanaman cinchona, pohon penghasil kina (quinine) di dataran tinggi Pulau Jawa. Inspirasi eksebisi ini adalah Great Exhibition yang diadakan tahun 1851 di London. Eksebisi ini bertujuan untuk mengenalkan dan meningkatkan cita rasa atas sumber daya alam dan hasil kerajinan Hindia Belanda kepada masyarakat sehingga mereka dapat memanfaatkannya untuk kepentingan komersil. Beberapa hasil kemajuan Hindia Belanda yang dipamerkan antara lain teknologi produksi gula, teknologi litografi, modifikasi alat bajak Eropa, perahu tradisional, koleksi ikan maupun tanaman. Semua objek tersebut dikumpulkan dari setiap karesidenan di seluruh kepulauan wilayah Hindia Belanda. Pada periode tersebut, keingintahuan atas pengetahuan alam sedang mewabah di kalangan masyarakat, sehingga eksebisi ini menjadi tujuan piknik terpopuler selama dua bulan (Goss, A., 2014). Kesuksesan ini menunjukkan bahwa melalui Pameran 1853, floracrat mampu membaca permintaan publik atas pengetahuan tertentu. Pada kasus Hindia Belanda, konsep eksebisi telah mengerucut pada strategi membaca pasar, dalam artian konsumen maupun target pengunjung.

Pembacaan atas minat (demand) ini kemudian mendasari produsen untuk mengadakan eksebisi yang bertujuan untuk kepentingan komersil. Maka trade fair menjadi ajang yang populer untuk asosiasi produsen yang memproduksi barang tertentu, biasanya satu tema, untuk memajang produk terbaru mereka di ruang publik. Unsur komersil tidak dibahas lebih lanjut sebab kajian ini terbatas pada eksebisi 
arsip. Bagaimanapun, konsep eksebisi untuk mempertemukan suatu objek dengan pengunjung di ruang publik menjadi konsep dasar eksebisi yang secara berkelanjutan dijalankan oleh penyelenggara eksebisi bidang apapun.

Kontinuitas dalam keberhasilan eksebisi sebagai sarana komunikasi di atas membuat lembaga kearsipan maupun penggiat arsip turut mengadopsinya sebagai salah satu program publik. Dalam lingkup pemerintah, lembaga kearsipan (yang disetarakan dengan perpustakaan dan museum) sebagai institusi memori memiliki kewajiban untuk mendiseminasikan informasi yang dimilikinya. Istilah diseminasi informasi ini lebih mengarah kepada pemahaman bahwa terdapat jenis informasi yang secara terbuka harus diberikan kepada masyarakat tanpa diminta (Widyarsono, $T$, 2014). Penyediaan informasi ini bertujuan untuk mengedukasi masyarakat tentang subjek tertentu.

\section{Rumusan Masalah}

Melalui konsep diseminasi informasi, eksebisi arsip mestinya dapat memberikan informasi baru yang sesuai dengan kebutuhan masyarakat pada saat itu. Maka, komunikasi yang dibangun mensyaratkan pemahaman spesifik atas pengetahuan yang telah dimiliki oleh target pengunjung. Spesifikasi di atas perlu dilakukan agar eksebisi arsip di Indonesia tidak terbatas pada penyajian arsip sebagai objek, tanpa mempertimbangkan konsep kuratorial untuk membangun komunikasi dengan publik. Untuk membatasi pembahasan, maka penelitian ini mengajukan pertanyaan penelitian yaitu bagaimana gambaran eksebisi arsip yang telah dilaksanakan di Indonesia? Selanjutnya, persoalan-persoalan kuratorial apa yang muncul dalam praktek eksebisi arsip?

\section{Tujuan Penelitian}

Tujuan dari penelitian ini adalah untuk mengetahui gambaran pelaksanaan eksebisi arsip di Indonesia. Gambaran ini, secara general dapat dievaluasi guna identifikasi persoalanpersoalan yang kerap muncul dalam perencanaan eksebisi arsip. Dengan mengetahui persoalan kuratorial, penyelenggara eksebisi (baik dari kalangan lembaga kearsipan atau non-lembaga kearsipan) dapat merencanakan eksebisi dengan mempertimbangkan keterkaitan objek dan konteks, yang dalam hal ini tergantung pada isu terkini dalam masyarakat.

\section{Metode Penelitian}

Kajian ini memakai metode studi pustaka dan observasi lapangan untuk mendapatkan data mengenai praktik eksebisi arsip di Indonesia. Kajian literatur digunakan untuk mencari perbandingan konsep mengenai eksebisi dan pemaknaan mengenai kuratorial. Sementara observasi lapangan dilakukan untuk melihat secara langsung bagaimana eksebisi arsip dilaksanakan. Dua eksebisi arsip yang dilaksanakan oleh institusi berbeda, yaitu institusi publik (Badan Perpustakaan dan Arsip Daerah Istimewa Yogyakarta) dan institusi privat (Indonesia Visual Art Archive) dikaji sebagai contoh kasus. Pada tahun 2016, BPAD mengadakan pameran arsip dengan tema transportasi, sementara IVAA mengadakan pameran arsip tahun 2017 dengan tema Kuasa 
Ingatan. Konten dalam kedua eksebisi kemudian dianalisis untuk kesesuaian objek dengan ide yang disampaikan. Terakhir adalah penulisan narasi berdasarkan data dan analisis yang telah didapatkan.

\section{Kerangka Pemikiran}

Pada tahun 1994, Heather Marie Gordon menulis tentang Archival Exhibition: Purposes and Principles yang membahas tentang teori dalam eksebisi arsip. Master thesis pada Universitas of British Columbia ini menekankan pada prinsip-prinsip yang harus diperhatikan pada eksebisi arsip sebelum pekerjaan teknis eksebisi seperti metode dan praktek dilakukan. Disebutkan bahwa dalam mempersiapkan eksebisi, gejala yang hampir selalu ditemukan dalam eksebisi arsip adalah penyelenggara yang terbatas menggunakan pendekatan museum tanpa mempertimbangkan pendekatan arsip, walaupun itu dilakukan oleh lembaga kearsipan.

Menurut Gordon (1994:3), alasan mengapa eksebisi dilakukan merupakan hal pertama yang harus ditetapkan dalam eksebisi arsip, daripada kegiatan teknis seperti display. Ketika alasan telah ditetapkan, maka tujuan eksebisi menjadi lebih spesifik, sehingga penyelenggara dapat memilih jenis eksebisi yang cocok untuk diterapkan. Jenis eksebisi yang umum dikenal antara lain eksebisi tetap, temporer atau keliling. Di Indonesia, klasifikasi ini merupakan pembagian eksebisi berdasarkan lama waktu penyelenggaraan eksebisi yang berpengaruh terhadap durasi display objek. Galeri Nasional Indonesia, melalui webnya http://galeri-nasional.or.id menjadi salah satu institusi yang memberikan pengertian dan menerapkan konsep atas pembagian ini. Eksebisi tetap adalah eksebisi yang berlokasi tetap dalam waktu yang lama, misalnya satu tahun. Sementara eksebisi temporer merupakan eksebisi yang berjangka sekitar satu minggu hingga satu bulan. Kemudian eksebisi keliling merupakan eksebisi singkat, sekitar 3-5 hari kemudian berpindah lokasi. Selanjutnya, penentuan atas tujuan eksebisi ini berkaitan dengan pendekatan tematis untuk membatasi objek.

Aspek paling krusial yang didiskusikan oleh Gordon adalah perlakuan terhadap objek arsip, baik secara intelektual maupun teknis. Secara intelektual, arsip tidak dapat disamakan dengan koleksi pustaka ataupun museum. Satu hal yang membedakan khazanah arsip dengan koleksi sumber informasi lain adalah keterikatan satu arsip dengan yang lainnya. Hal ini berarti pendekatan fonds menjadi lebih memungkinkan untuk digunakan sebagai dasar seleksi daripada pendekatan tingkat individual (Gordon, H. M., 1994). Seleksi pada tingkat fonds ini juga kemudian berpengaruh terhadap bagaimana display direncanakan agar memberikan sebuah alur yang dapat dipahami.

Diskusi Gordon tentang perlunya pemahaman ilmu kearsipan dalam eksebisi arsip juga sepaham dengan kajian Kalfatovic berjudul Creating a Winning Online Exhibition, a Guide for Library, Archives and Museum. Dalam pembahasannya, Kalfatovic menyebutkan bahwa suatu koleksi objek tidak lantas dapat disebut sebagai eksebisi. Koleksi hanya dapat disebut eksebisi jika display berisi objek yang dipilih secara hati-hati agar dapat mengilustrasikan tema dan diikat dengan suatu 
narasi. Ide sebagai konteks kemudian diletakkan pada persiapan pertama dalam eksebisi. Selanjutknya persiapan difokuskan pada bagaimana cara menghubungkan ide/tema, objek dan narasi yang berbentuk naskah kuratorial (Kalfatovic, M. R., 2002).

Lebih lanjut, dalam kajian Ernst van Alphen berjudul Staging the Archive: Ydessa Handeles and Hanne Darboven, arsip ditempatkan pada posisi strategis yaitu agen yang aktif untuk membentuk identitas personal serta memori sosial dan kultural. Namun, agen aktif ini hanya bisa berjalan jika ia diatur sedemikian rupa agar menghasilkan pemahaman yang logis. Informasi baru hanya bisa diungkap jika arsip dirangkai sesuai konteks. Kini, kajian kritis tidak lagi menganggap arsip sebagai objek netral/tidak memihak sebab ada campur tangan struktur masyarakat pembentuknya. Oleh sebab itu, koleksi arsip dapat menjadi identitas tempat di mana ia tercipta (van Alphen, E., 2014).

Hingga kini, eksplorasi arsip melalui eksebisi masih sangat sedikit di Indonesia, apalagi kajian tentang bagaimana eksebisi arsip dilakukan. Oleh sebab itu, kajian ini ingin memberikan ulasan singkat tentang bagaimana lembaga kearsipan maupun organisasi privat melaksanakan eksebisi arsip. Secara praktis, eksebisi arsip dapat menjadi sarana komunikasi antara lembaga kearsipan dan masyarakat guna edukasi tentang pengetahuan sejarah dan praktik dokumentasi. Namun lebih jauh lagi, eksebisi dapat pula berfungsi untuk mengenalkan sumber pengetahuan yang reliabel. Hal ini relevan untuk membantu publik untuk menyeleksi informasi di tengah fenomena banjir hoax (pemberitaan atas informasi palsu) yang terjadi akhir-akhir ini.
Untuk mencapai tujuan itu, maka penyelenggara harus terlebih dahulu memahami bagaimana menampilkan arsip sehingga tujuannya dapat ditangkap oleh masyarakat.

\section{PEMBAHASAN}

Gagasan untuk mempertemukan produsen atau seniman atau pemilik koleksi dengan pengunjung merupakan konsep komunikasi yang bertujuan untuk menyampaikan suatu ide. Subjek yang disampaikan tidak hanya terbatas pada ide sebagai materi pengetahuan baru, namun juga dapat berarti pengetahuan lama yang diputar ulang untuk menumbuhkan kesadaran. Dalam kedua model pemilihan subjek atau tema di atas, satu hal yang perlu diperhatikan adalah bagaimana menempatkan konteks dalam eksebisi.

Hampir semua eksebisi pasti membawa ide di dalamnya. Ide ini lantas termanifestasi dalam tujuan yang ingin dicapai. Dalam usaha untuk mencapai tujuan tersebut dibutuhkan koleksi objek dan display yang mendukung sebuah alur cerita (storyline). Merujuk pada Kalfatovic (2002:9), ide dan tujuan lantas membentuk tema yang kemudian menentukan koleksi objek yang diseleksi. Selanjutnya, koleksi terpilih diikat dengan narasi yang dapat dikemas dalam naskah kuratorial. Dalam naskah kuratorial, selain alur cerita, tercantum pula deskripsi objek yang dipilih dan darimana objek didapatkan.

Pemahaman atas objek eksebisi menjadi aspek selanjutnya yang penting untuk dibahas. Perbedaan sifat media, menjadi pembeda antara arsip dengan buku (perpustakaan), artefak (museum) dan benda seni (galeri) dalam 
eksebisi. Arsip, ketika diciptakan dan digunakan memiliki informasi yang bersifat tertutup. Dalam artian, terdapat batasan bahwa informasi dalam arsip hanya digunakan pada tingkat internal saja. Hal ini berbeda jika dibandingkan dengan buku, artefak dan benda seni yang informasinya bersifat terbuka sejak diciptakan. Namun, terdapat tingkatan arsip yang memungkinkan informasinya berubah sifat menjadi terbuka, yaitu tahapan arsip statis. Untuk itu, eksebisi hanya dapat menggunakan arsip yang telah masuk ke dalam status arsip statis.

Persoalan kedua adalah pola penataan arsip sejak ia berstatus dinamis. Penataan arsip harus menempatkan fonds sebagai klasifikasi utama (Sweeney, S., 2008). Model ini digunakan sebab arsip adalah hasil samping suatu kegiatan administratif, sehingga kultur penataannya berdasar tugas pokok dan fungsi organisasi penciptanya. Hal ini terus berlanjut ketika arsip menjadi statis. Penataan jenis ini memang tidak didesain untuk pencarian topik tematis. Perkembangan alat temu balik (finding aids) elektronik dalam bentuk search engine seperti google, memungkinkan penelusuran arsip tematis tanpa membutuhkan banyak waktu. Beberapa instansi pemilik arsip statis di Eropa dan Amerika kini telah menyediakan sarana akses tersebut. Perkembangan sarana akses elektronik online ini pun sudah diadopsi oleh beberapa instansi di Indonesia, seperti Arsip Nasional Republik Indonesia, Dinas Perpustakaan dan Kearsipan Daerah, Indonesian Visual Art and Archives maupun pusat data lainnya. Meskipun penelusuran arsip elektronik ini mudah dilakukan, namun campur tangan arsiparis masih menjadi kebutuhan dalam konteks eksebisi. Untuk itu, perkara pengumpulan objek untuk eksebisi memerlukan kerjasama antara arsiparis dan kurator.

Berbeda dengan profesi arsiparis yang terlebih dahulu popular, profesi kurator hanya sedikit sekali dikenal di Indonesia. Kurator merupakan seseorang yang bertanggungjawab dalam penyelenggaraan suatu eksebisi. Museum sebagai lokasi tetap eksebisi kemudian mempekerjakan kurator sebagai penanggung jawab atas keberlangsungan eksebisi. Selain bertanggung jawab selama pelaksanaan eksebisi, kurator juga melakukan seleksi objek dan bagaimana gaya menghadirkan objek kepada masyarakat. Ketidakpopuleran kurator di Indonesia, dan juga bangkitnya apresiasi privat atas eksebisi menyebabkan kurator independen lebih banyak muncul daripada kurator tetap pada suatu museum.

Mikke Susanto, salah satu kurator independen dari Institut Seni Indonesia di Yogyakarta berpendapat bahwa profesi kurator merupakan profesi yang masih "muda" di Indonesia, sehingga profesi ini tidak berdiri sendiri. Profesi kurator dikenalkan kepada publik Indonesia pertama kali oleh Jim Supangkat (seniman sekaligus kurator independen) sekitar tahun 1995 ketika museum di Indonesia dituntut untuk mengacu pada standar internasional (wawancara dengan Mikke Susanto, 26 Oktober 2018). Walaupun beberapa museum di Indonesia telah mengenal kurator, namun banyak praktek eksebisi yang tidak menggunakan kurator dan tetap berjalan. Identifikasi persoalan di atas bukan pada profesi kurator, namun pemahaman atas kerja kuratorial. Dalam hal ini, bisa saja seniman, ataupun profesi keahlian lain seperti 
sejarawan, arkeolog maupun antropolog bertindak sebagai kurator. Paduan ini disebutnya sebagai figure hibrid, yang berarti satu profesi namun dia dapat menjadi agen ganda dalam sebuah proses kerja (Susanto, M., 2004).

Pengakuan atas figure hibrid dapat menjadi keuntungan bagi arsiparis yang menjadi kurator dalam eksebisi arsip. Keleluasaan dalam figure hibrid berguna untuk meminimalisir perbedaan pemahaman proses kuratorial terhadap objek arsip. Objek arsip, pada prinsipnya memiliki kekhususan untuk berdiri secara berkelompok, tidak seperti objek museum yang dapat berdiri secara individu (Gordon, H. M., 1994). Selain itu, kultur arsip lain juga mesti dipertimbangkan dalam lengkah kuratorial umum.

Berikut analisis lima tahapan kerja kuratorial secara umum yang diajukan oleh Hans Jorg Furst, sebagaimana dikutip pula oleh Mikke Susanto (Susanto, M., 2004), dengan penyesuaian terhadap objek arsip.

\section{Akuisisi}

Tahapan ini merupakan langkah untuk memperoleh atau menambah koleksi. Dalam konteks museum secara umum, penambahan koleksi dapat dilakukan dengan cara membeli (purchasing) dan menerima hibah dari donatur. Dalam ilmu kearsipan, akuisisi merupakan tahap pertama dalam Manajemen Arsip Statis (Archives Management) yang berarti penambahan khazanah arsip statis melalui pengambilalihan arsip statis dan hak pengelolaannya dari instansi pencipta (UU No.43 Th.2009). Tahap akuisisi dalam ilmu kearsipan didahului dengan pendataan, seleksi berdasarkan nilai guna (evidensial, informasional dan intrinsik) dan transfer arsip ke lembaga kearsipan.
Dalam teknis eksebisi arsip yang tidak diselenggarakan oleh lembaga kearsipan, penambahan koleksi ini dapat berarti pengumpulan koleksi dari berbagai sumber pencipta. Dalam artian, kurator dapat membuka sesi seleksi dan mengundang pencipta/pemilik arsip yang prospektif untuk dipinjam. Cara lain yang dapat dilakukan adalah kurator mendatangi pemilik arsip dan mengajukan pinjaman arsip sesuai tema.

\section{Dokumentasi}

Secara sederhana, dokumentasi di sini berarti inventaris koleksi yang telah diakuisisi. Pencatatan meliputi asal usul koleksi, termasuk diantaranya berkas yang dihasilkan ketika proses akuisisi dilakukan, seperti surat pembelian, peminjaman maupun perjanjian hibah. Dalam tahapan ini, penelusuran mengenai asal usul juga dilakukan untuk mendapatkan informasi tentang sejarah lembaga pencipta. Penelusuran ini juga dapat membantu kurator untuk mengetahui konteks penciptaan arsip, sehingga mempermudah display dalam ruang pamer.

\section{Pemeliharaan}

Baik objek museum maupun arsip, pemeliharaan merupakan tahapan terpenting untuk menjaga akurasi dan keaslian objek. Pemeliharaan objek berimplikasi pada dua hal, pertama keselamatan objek itu sendiri, kedua yaitu apresiasi masyarakat/ pengunjung terhadap objek. Pada kasus objek arsip, pemeliharaan atau preservasi dilakukan dengan dua metode yaitu preventif dan kuratif. 


\section{Penyimpanan}

Proses penyimpanan ini terkait dengan preservasi preventif, yaitu bagaimana menjaga keadaan supaya mendukung objek tetap terpelihara. Kerusakan fisik merupakan ancaman pertama terhadap hilangnya informasi sehingga kondisi penyimpanan harus dijaga. Beberapa kondisi yang mengancam kelestarian arsip, sebagaimana juga koleksi museum, antara lain paparan sinar matahari dan debu, kelembaban udara dan suhu yang tinggi. Oleh sebab itu, prasarana pendukung seperti $\mathrm{AC}$, pengukur kelembaban mutlak diperlukan. Untuk mendukung pemeliharaan ini, maka lokasi yang disarankan untuk eksebisi arsip adalah eksebisi dalam ruangan (indoor).

\section{Gaya/Jenis Pameran}

Dalam tahapan terakhir, pemilihan jenis pameran dilakukan sesuai dengan koleksi yang dipamerkan. Pada eksebisi arsip, dengan menimbang kerentanan objek, maka eksebisi temporer menjadi pilihan yang disarankan. Eksebisi tetap tidak menjadi prioritas pilihan sebab display yang terlalu lama dapat menimbulkan ancaman pada kondisi fisik arsip. Apalagi jika ruangan tidak disertai dengan pendingin udara dan pengatur kelembaban. Ancaman kerusakan juga dapat terjadi saat pemindahan arsip sehingga eksebisi keliling juga tidak menjadi opsi yang disarankan karena aktivitas bongkar pasang saat transportasi arsip.

Persoalan lain dalam eksebisi arsip yang mungkin terjadi adalah pemahaman masyarakat
Indonesia atas arsip itu sendiri. Ketika istilah arsip dikenalkan, lembaga kearsipan cenderung mengasosiasikannya dengan kerja administrasi formal. Hal ini dapat dipahami sebab istilah arsip secara historis memang dikenalkan oleh lembaga pemerintah. Namun, pemahaman ini berakibat pada kategori arsip yang spesifik dan sempit. Dokumen yang tidak memiliki struktur dan bukan berasal dari lembaga kearsipan lantas dianggap sebagai non-arsip. Pemahaman ini tidak memuaskan kalangan pengguna seperti sejarawan, yang menganggap bahwa arsip merupakan suatu hal yang hegemonik. Pengkajian terhadapnya menyimpulkan bahwa arsip bukan merupakan entitas yang netral. Penciptaannya cenderung mengacu hanya pada apa yang diputuskan penting untuk direkam. Dalam historiografi, rekonstruksi masa lalu yang sepenuhnya bersandar pada arsip resmi dari lembaga publik membuat penggambaran peristiwa menjadi kurang komperehensif. Oleh sebab itu, sejarawan cenderung memperluas arti arsip sebagai rekaman peristiwa masa lalu, tanpa membatasi siapa penciptanya, dengan atau tanpa struktur. Koran, buku harian, lukisan maupun keterangan lisan menjadi sumber informasi lain yang layak dipertimbangkan.

Perbedaan cara pandang antara lembaga kearsipan dan pengguna di atas menyebabkan munculnya perbedaan karakter eksebisi yang diselenggarakan oleh lembaga publik dan privat. Karakter yang tidak bisa dihindari memang terletak pada khazanah yang dihadirkannya kepada khalayak. Lembaga kearsipan cenderung hanya mempromosikan khazanah yang dimilikinya. Praktik ini tidak dapat dinegasikan terkait posisi eksebisi yang ditujukan sebagai 
program publik untuk memasyarakatkan arsip (Pambudi, A.G., 2017). Sementara khazanah pada eksebisi yang diselenggarakan oleh lembaga privat cenderung lebih dapat mengeksplorasi objek, sebab khazanah dapat dipinjam dari manapun. Kekayaan ini juga membuat eksebisi lebih komunikatif terhadap target yang disasar.

Lebih lanjut, kajian terhadap kerja kuratorial dapat dilihat dalam dua eksebisi arsip yang telah diobservasi. Pertama adalah eksebisi arsip tahunan milik lembaga kearsipan tingkat provinsi yaitu Badan Perpustakaan dan Arsip Daerah Yogyakarta, dan kedua adalah eksebisi dari organisasi privat bernama Indonesian Visual Art and Archives. Mengenai tema, IVAA memiliki tema yang lebih luas yaitu kuasa ingatan. Melalui eksebisi ini, tujuan IVAA adalah untuk menjelaskan kepada masyarakat bahwa kerja pengarsipan merupakan sebuah kerja politis (IVAA Guide Book, 2017). Sementara BPAD menampilkan tema yang lebih sederhana, yaitu koleksi arsip yang bertema transportasi di Yogyakarta.

Baik BPAD maupun IVAA telah memiliki ide/tema dan objek yang spesifik. Namun, IVAA terlihat lebih aktif mempublikasikan narasi kuratorial dalam bentuk guide book dan disebarkan kepada pengunjungnya. Narasi kuratorial dapat disatukan dengan katalog objek yang disertai informasi darimana objek berasal. Selain itu, narasi juga berguna untuk menyampaikan kepada khalayak alasan tentang konteks yang dipilih oleh kurator, juga tentang tujuan diadakannya eksebisi. Penjelasan di dalamnya dapat digunakan untuk memberikan pengetahuan awal khalayak tentang interpretasi objek yang ditampilkan. Sementara tujuan BPAD menampilkan eksebisi arsip tahun 2016 dengan judul 'Harmonisasi dalam Transportasi di Yogyakarta' di Sasono Hinggil dimaksudkan untuk memberikan gambaran transportasi yang pernah beroperasi di Yogyakarta. Selanjutnya, diharapkan melalui gambaran atas keharmonisan antara transportasi tradisional dan modern, pemerintah dapat merencanakan manajemen transportasi yang lebih baik (Kompas, 29 Agustus 2016).

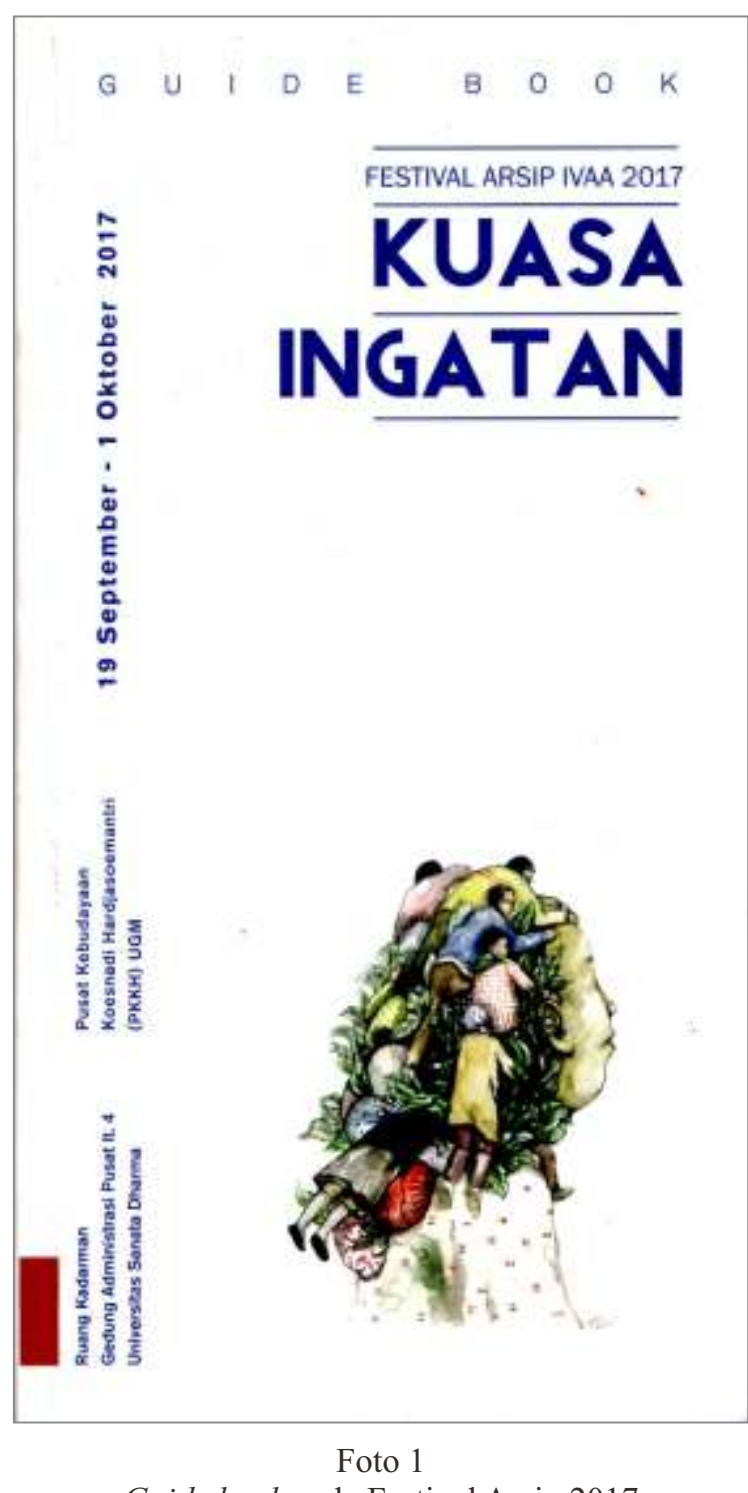

Guide book pada Festival Arsip 2017 yang diselenggarakan oleh Indonesian Visual Art Archives di Pusat Kebudayaan Koesnadi Hardjosoemantri dan Universitas Sanata Dharma. 
Kedua jenis eksebisi di atas tidak dapat begitu saja diperbandingkan tanpa melihat siapa penyelenggara eksebisi untuk memahami kultur organisasi yang mempengaruhi perspektif dalam masing-masing eksebisi. BPAD merupakan organisasi resmi pemerintah yang bergerak dalam pengelolaan arsip administratif pemerintahan. IVAA juga merupakan organisasi yang memelihara arsip, namun berbasis komunitas sehingga bersifat swasta. Selain karakter publik maupun swasta, karakter arsip yang disimpan juga turut mempengaruhi pola eksebisi. BPAD memiliki pemahaman spesifik tentang arsip, yaitu hasil dari kegiatan administratif, sementara IVAA cenderung memiliki kebebasan pemahaman atas arsip, terutama arsip dari komunitas seni.
Spesifikasi lantas berlanjut pada objek yang dipilih. Jika BPAD cenderung eksplisit menampilkan koleksi, IVAA menampilkan arsip yang lebih artistik dalam berbagai media. Kedua eksebisi menawarkan perspektif historis, namun menampilkan kemasan yang berbeda. BPAD lebih fokus menampilkan objek yang orisinil, sementara IVAA fokus kepada bagaimana pesan itu disampaikan. Pertanyaan selanjutnya adalah mana yang lebih penting? Orisinalitas atau kreatifitas? Dari segi ilmu kearsipan, seperti juga disetujui oleh beberapa ahli, menampilkan objek orisinil merupakan keharusan. Hal ini terkait dengan visi atau pesan yang dibawa oleh lembaga kearsipan untuk mengedukasi masyarakat dan mempromosikan fungsi lembaga kearsipan. Sementara IVAA yang lebih dekat

\begin{tabular}{|c|c|}
\hline Kategori & Indikator \\
\hline $\begin{array}{l}\text { Kesadaran penonton } \\
\text { (Audience awareness) }\end{array}$ & $\begin{array}{l}\text { Target pengunjung teridentifikasi, sehingga dapat dipetakan keberhasilan } \\
\text { pemahaman atas ide yang disampaikan. Untuk mempermudah penyampaian ide, } \\
\text { maka konten dan desiain harus disesuaikan dengan target. }\end{array}$ \\
\hline Evaluasi (evaluation) & $\begin{array}{l}\text { Umpan balik dari target dapat terjaring, misalnya dengan meminta setiap } \\
\text { pengunjung untuk menulis kesan dan saran. Kedua dengan cara berinteraksi } \\
\text { langsung dengan pengunjung secara acak dalam acara pendukung eksebisi, } \\
\text { misalnya seminar atau workshop. }\end{array}$ \\
\hline Konten (content) & $\begin{array}{l}\text { Narasi, maksud dan perspektif eksebisi teridentifikasi dan berhasil } \\
\text { dimunculkan; } \\
\text { Metodologi pemilihan konten sesuai dengan teori (kearsipan maupun } \\
\text { kuratorial); } \\
\text { Pilihan media dapat mengkomunikasikan konten. }\end{array}$ \\
\hline Koleksi (collection) & $\begin{array}{l}\text { Objek mengekspresikan ide; } \\
\text { Originalitas objek tersajikan; } \\
\text { Masalah konservasi dan pengamanan objek ditangani dengan tepat. }\end{array}$ \\
\hline Komunikasi & $\begin{array}{l}\text { Pengunjung dapat menangkap ide eksebisi, dalam artian pemilihan objek, media } \\
\text { dan storyline mudah diikuti. }\end{array}$ \\
\hline Desain dan produksi & $\begin{array}{l}\text { Pilihan estetika sesuai dengan tema dan tone warna dalam eksebisi; } \\
\text { Media baru untuk reinterpretasi digunakan (misal: powerpoint, movie player, } \\
\text { sound recording, hologram, dan lain-lain). }\end{array}$ \\
\hline $\begin{array}{l}\text { Keamanan dan } \\
\text { kenyamanan }\end{array}$ & $\begin{array}{l}\text { Display, pencahayaan dan tata lantai tidak berbahaya bagi pengunjung; } \\
\text { Label/kartu deskripsi narasi mudah dibaca; } \\
\text { Terdapat tempat duduk dalam area eksebisi. }\end{array}$ \\
\hline
\end{tabular}

Gambar 1

Standar evaluasi kerja kuratorial dalam suatu eksebisi.

Sumber: elaborasi dari American Alliance of Museums, Standards of Museums Exhibitions and Indicators for Excellence, 2012. 
dengan bidang seni, menganggap kreatifitas perlu untuk menjangkau target yang disasar, yaitu masyarakat pemerhati seni. Objek tidak harus berbentuk arsip bermedia konvensional, namun objek juga dapat menampilkan sesuatu yang tak terbaca, sehingga kekuatan komunikasi untuk menginterpretasikan objek berada pada naskah kuratorial yang dihadirkan.

Narasi dalam naskah kuratorial yang mengikat ide dengan objek mesti mengandung beberapa unsur, antara lain alur, penokohan, latar waktu dan tempat, serta nilai yang ingin ditampilkan (Hidajat, H., 2017). Alur cerita maju (prospektif) atau mundur (retrospektif) dapat menjadi pilihan, namun jalan cerita lebih baik ditata secara kronologis untuk mengarahkan alur berpikir pengunjung. Dalam kedua eksebisi, alur cerita tidak nampak rapi secara kronologis sebab beberapa objek masih ditata secara acak. Berbeda dengan alur, penokohan merupakan unsur yang jelas terlihat dalam kedua eksebisi. Masingmasing menampilkan dinamika dalam hubungan rakyat dengan penguasa. Berbicara tentang latar waktu dan tempat, pembatasan waktu terlihat lebih menonjol pada eksebisi BPAD yang terlihat dari angka tahun yang tercantum dalam deskripsi.

Analisis terhadap pelaksanaan eksebisi arsip secara keseluruhan dapat menggunakan beberapa standar evaluasi kuratorial yang dirumuskan oleh American Alliance of Museums.

Mengacu pada standar tersebut, maka kerja kuratorial memang mencakup perencanaan hingga eksebisi berakhir. Dalam hal ini, baik pameran BPAD maupun IVAA tepat dalam membidik sasaran yang diwakili dalam pemilihan lokasi eksebisi. Lokasi memang menjadi magnet untuk menangkap pengunjung yang ditargetkan. Lokasi Siti Hinggil di AlunAlun Selatan menjadi strategis sebab target adalah masyarakat bawah. Alun-alun, secara historis merupakan ruang publik yang cukup popular untuk berinteraksi, sehingga eksebisi dapat menarik pengunjung tanpa promosi berlebihan. Target masyarakat ini pun sesuai dengan misi BPAD sebagai organisasi publik yang berperan untuk menyimpan dan memberikan layanan arsip sebagai memori kolektif. Oleh sebab itu, pemilihan objek terbatas pada arsip foto (still image) dan arsip tekstual. Namun, jika ditujukan kepada masyarakat bawah, maka objek sederhana lebih disarankan sebab tidak terlalu berat untuk dicerna. Di lain pihak, pilihan lokasi eksebisi Kuasa Ingatan yang dilaksanakan oleh IVAA yaitu Pusat Studi Koesnadi Hardjosoemantri (berada dalam kompleks UGM) juga sesuai dengan target yaitu masyarakat terpelajar, seperti praktisi, budayawan, seniman maupun mahasiswa.

Tantangan selanjutnya dalam eksebisi arsip adalah keragaman dalam penggunaan media. Bermacam media informasi baru seperti audio maupun video perlu digunakan untuk menghindari kejemuan dalam eksebisi arsip. Pertimbangan penggunaan media baru dalam eksebisi termasuk kerja kuratorial dalam mempelajari budaya informasi di masyarakat. Oleh sebab itu, kurator eksebisi arsip perlu memperhatikan perubahan budaya informasi dari masa ke masa yang meliputi jenis informasi yang dibutuhkan dan jenis media yang banyak diminati. Melalui observasi, IVAA telah menggunakan media yang lebih beragam dan modern daripada BPAD. Namun, hal ini tidak 
berarti BPAD tidak dapat menjangkau kesadaran pengunjung melalui eksebisinya. Media foto dan lokasi yang dipilih BPAD justru menampilkan atmosfer nostalgia masa lalu karena memiliki batasan waktu yang jelas. Selain itu, kedua eksebisi tetap berhasil menjangkau kesadaran penggunjung dengan adanya seminar untuk komunikasi interaktif dengan pengunjung.

\section{KESIMPULAN}

Berdasarkan pembahasan di atas, dapat diketahui bahwa akar permasalahan kuratorial pada eksebisi arsip di Indonesia terletak pada pemahaman atas suatu objek yang disebut arsip. Pemahaman atas berbagai definisi arsip kemudian turut mempengaruhi kerja kuratorial, terutama dalam menyeleksi arsip yang ditampilkan. Dalam hal seleksi, sebagaimana arsiparis yang harus belajar bagaimana kurasi dilakukan dari perspektif seni, kurator eksebisi arsip non-arsiparis juga perlu belajar identifikasi keterkaitan antar objek yang menjadi karakteristik arsip. Pendekatan fonds dapat menjadi area yang dapat dieksplorasi lebih lanjut.

Kedua eksebisi arsip yang diobservasi merupakan praktik yang masih sedikit ditemui di Indonesia, sehingga keberadaannya patut diapresiasi. Apresiasi ini bertujuan untuk mempromosikan lebih luas tentang kerja pengarsipan di berbagai lapisan masyarakat. Eksebisi arsip di Indonesia dapat menjadi salah satu program yang diarahkan untuk produksi pengetahuan. Secara spesifik, dengan menampilkan kebaruan (novelty) dalam setiap eksebisi, lembaga pengarsipan dapat menempatkan arsip sebagai sumber informasi reliabel untuk produksi pengetahuan yang sama sekali belum pernah ada atau memberikan fakta baru untuk memikirkan ulang narasi yang telah eksis sebelumnya.

\section{DAFTAR PUSTAKA}

\section{Buku dan Jurnal}

Pambudi Adhie Gesit. 2017. Dari Sumber Informasi ke Galeri Pengetahuan, Pendekatan Kearsipan pada Pameran Arsip Statis. Jurnal Khazanah Yogyakarta: Arsip Universitas Gadjah Mada. 10(1).

Alphen, Ernst van. Staging the Archive: Ydessa Handeles \& Hanne Darboven in Journal of Taipei Fine Arts Museum. 28.

Goss, Andrew. 2014. Belenggu Ilmuwan dan Pengetahuan, dari Hindia Belanda sampai Orde Baru. Depok, Komnitas Bambu.

Kalvatovic, Martin R. 2002. Creating a Winning Online Exhibition, a Guide for Library, Archives and Museum. American Library Association.

Susanto Mikke. 2004. Menimbang Ruang Menata Rupa. Yogyakarta, Galang Press.

Sweeney, Shelley. 2008. The Ambiguous Origins of the Archival Principle of Provenance in Libraries \& the Cultural Records, University of Texas Press. Vol.43 No.2.

Widyarsono Toto. 2014. Modul Universitas Terbuka: Diseminasi Informasi. Jakarta: Universitas Terbuka.

\section{Thesis}

Gordon, Heather Marie. 1994. Archival Exhibitions Purposes and Principles, Master thesis on The University of British Columbia.

\section{Undang-undang}

Undang-Undang Republik Indonesia Nomor 43 Tahun 2009 tentang Kearsipan. Arsip Nasional Republik Indonesia. Jakarta. 
Guide:

American Alliance of Museums, Standards of Museums Exhibitions and Indicators for Excellence.

IVAA, Guide Book Festival Arsip IVAA 2017, Kuasa Ingatan, Yogyakarta: Pusat Kebudayaan Koesnadi Hardjosoemantri, 19 September-1 Oktober 2017.

\section{Sumber internet:}

Galeri Nasional Indonesia: http://galerinasional.or.id/halaman/357 temporer_exhibition.

Bob Mondello, a History of Museum, the Memory of Mankind in Special Series, Museum in the 21st Century. National Public Radio.Inc, 2008. Website: https://www.npr.org/templates/story/story. php? storyId=97377145.

Andong dan Becak, Sebuah Refleksi Sistem Transportasi di Yogyakarta pada Kompas, 29 Agustus 2016. Berita dapat dilihat di we bsite Kompas: https:// sains.kompas.com/read/2016/08/29/1925 0501/andong.dan.becak.sebuah.refleksi.si stem.transportasi.di.yogyakarta. 